\title{
Molecular phylogeny of wild Hops, Humulus lupulus $L$.
}

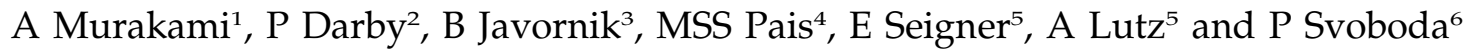 \\ ${ }^{1}$ Kirin Brewery Co., Ltd, Research Laboratory for Brewing, 1-17-1 Namamugi Tsurumi-ku, Yokohama 230-8628, Japan; ${ }^{2}$ East Malling \\ Research, Department of Hop Research, Wye, Ashford, Kent TN25 5AH, England; ${ }^{3}$ Center for Plant Biotechnology and Breeding, \\ Biotechnical Faculty, University of Ljubljana, Jamnikarjeva 101, SI-1000 Ljubljana, Slovenia; ${ }^{4}$ Laboratory of Plant Biotechnology - \\ ICAT, Edificio ICAT, Campo Grande 1749-016, Lisbon, Portugal; ${ }^{5}$ Bayer, Landesanstalt für Landwirtschaft, Institut für Pflanzenbau und \\ Pflanzenzuechtung, Arbeitsbereich Hopfen, Huell 5 1/3, D-85283 Wolnzach, Germany; ${ }^{6}$ Hop Research Institute Co., Ltd, Kadaňská 2525, \\ 43846 Žatec, Czech Republic
}

\begin{abstract}
We have analysed wild hops collected widely from the Northern Hemisphere, assessing the genetic diversity and the geographical distribution of haplotypes, to investigate the evolution and phylogeny of hops, Humulus lupulus. The haplotypes were characterized by the nuclear ribosomal DNA spacer region (length and DNA sequence) and chloroplast DNA noncoding regions (DNA sequences). The results indicated that primary divergence into European (including Caucasus and Altai hops), and Asian-North American types, was $1.05 \pm 0.28$ to $1.27 \pm 0.30$ million years ago. Although an Eastern boundary for European nuclear haplotype distribution was unclear due to the ambiguous origin of Northern Chinese samples, the
\end{abstract}

Keywords: chloroplast DNA; Humulus; ribosomal DNA

\section{Introduction}

The hop plant, Humulus lupulus, is a dioecious perennial species, and only female cones are used for beer brewing. Hops are used to impart bitterness, flavour and preservation properties to modern beers, as established in Europe. However, similar beers first appeared in Ancient Mesopotamia and Egypt as early as the Neolithic (Behre, 1999).

The genus Humulus consists of three species, $H$. lupulus, H. japonicus and H. yunnanensis (Small, 1978; Neve, 1991). Wild hops of $H$. lupulus are widely distributed throughout the Northern Hemisphere, Europe, Asia and North America (Small, 1978; Neve, 1991). Small (1978) classified H. lupulus into a number of taxonomic varieties; var. lupulus for European wild hops and cultivars, var. cordifolius for Japanese wild hops, and var. neomexicanus, pubescens and lupuloides, for North American hops. The varieties differ in morphological characteristics such as number of lobes on the leaf and hairs on the bine. North American and Japanese wild hops resemble each other morphologically, suggesting a genetically close relationship, while they differ widely from European hops (Neve, 1991).

Correspondence: Current address: A Murakami, Kirin Brewery Co., Ltd, Shiga, 1600 Binmanji, Tagacho Inukamigun, Shiga 522-0342, Japan.

E-mail:m-atsushi@kirin.co.jp

Received 3 July 2005; accepted 10 April 2006; published online 10 May 2006
European hop group showed a wide geographical distribution across Eurasia from the Altai region to Portugal. The low genetic variation in this group suggested rapid and recent expansion. The North American hop group showed high diversity, and is considered to include hops that have migrated from Asia. Japanese and Chinese hops were identified as genetically distinct. This study has shown that wild hops in each growing region are genetically differentiated with considerable genetic diversity. It gives insights into the evolution and domestication of hops that are discussed.

Heredity (2006) 97, 66-74. doi:10.1038/sj.hdy.6800839; published online 10 May 2006

Commercial hop production occurs in many countries. Hop cultivars have been roughly classified into two groups, one group consisting of European landraces while the other has a genetic composition derived from North American wild hops (Seefelder et al, 2000; Jakše et al, 2001). However, analysis of five microsatellite loci showed limited genetic variation among major hop cultivars throughout the world. It has been suggested that the use of a restricted number of hop varieties for breeding has caused this narrow range of genetic variation (Jakše et al, 2001).

Some important characteristics of modern cultivars, such as disease resistance and high levels of alpha-acids (which are converted to bitter compounds in beer), are known to originate from wild hops (Neve, 1991). Pillay and Kenny (1996) reported a difference between European and North American hops in the 18s-26s ribosomal DNA length (rDNA). Ribosomal DNA occurs in large tandem repeats, which are affected by gene conversion and unequal crossing over. The intergenic spacer (IGS) was found to exhibit sufficient variation to enable the study of closely related cultivars, populations and individuals. Murakami (2001) also found significant nucleotide variation among wild hops in the external transcribed spacer (ETS) of the IGS region of 18s-26s rDNA (IGS), although the number of wild hops studied was limited.

The history of hops and their usage is surrounded by uncertainty. It is not known when hops were first used 
for beer brewing in Europe (Wilson, 1975; Delyser and Kasper, 1994). How hops were domesticated in Europe is also unknown although pollen records suggest hop usage had already started in the early Roman era (Wilson, 1975). It has been assumed that the origin of European cultivars and wild hops was either from central Europe, brought by people migrating from the East, or simply from cultivation of native wild hops. However, it has been suggested that European wild hops themselves originated from past introductions and they do not represent an autochthonous European plant (Rybáček, 1991; Moir, 2000). Little is known about the phylogenetic relationships among wild hops and their genetic variability, nor about their origin and migration routes (Neve, 1991; Pillay and Kenny, 1996; Murakami, 2000, 2001). Phylogenetic analysis among wild hops from around the world could give insights into the evolution and domestication of hops.

In this paper, we analyze a large number of wild hops collected from around the world to assess their genetic diversification based on nuclear and chloroplast DNA differences. Nuclear DNA analyses made use of the IGS length of $18 \mathrm{~s}-26 \mathrm{~s}$ rDNA and the $537 \mathrm{bp}$ sequence of ETS. A total of 12 noncoding regions of chloroplast DNA (cpDNA) were sequenced ( $8 \mathrm{~kb}$ in total nucleotides). Such regions are generally considered to be free from evolutionary constraint and where a relatively high rate of molecular evolution is expected (Demesure et al, 1995).

\section{Materials and methods}

\section{Plant materials}

The wild hops, H. lupulus, used in this study were collected widely from the Northern Hemisphere: European countries (Austria, Czech Republic, Germany, Hungary, Italy, Poland, Portugal and Ukraine), the Caucasus region (located between the Black Sea and the Caspian Sea), the Altai region (close to western China, located on boundaries of Russia, Mongolia, Kazakhstan and China), China, Japan and North America (Canada and the USA) as shown in Figure 1 and Appendix 1. Unfortunately, records of the locality of collection of Chinese hops were ambiguous. Three samples from China were recorded as just 'Mongolia', which could be either Mongolia or inner Mongolia autonomous region, Similarly, two Chinese samples were described as 'Southern Chinese region', which could be either Sichuan or Yunnan province. In this study, the 'Mongolia' samples are described as Northern Chinese hops, and the Sichuan or Yunnan province samples are termed Southern Chinese hops.

All materials were maintained as rootstocks, at the authors' organizations. H. japonicus was collected in Yokohama city, Japan.

\section{DNA analyses}

DNA was extracted using a Plant DNA extraction mini kit (Quiagen), followed by purification according to Murakami (2000).

IGS length and ETS sequence were examined among 147 individuals as detailed in Table 1, and PCR was performed according to the method of Murakami (2000). PCR fragments were purified by a High Pure PCR Products Purification kit (Boehringer Mannheim), and sequencing of ETS nucleotides was performed by the method described by Murakami (2001).

For the cpDNA analyses, primers (Table 2) designed by Demesure et al (1995) for specific noncoding regions were used, and 125 individuals were examined (Table 1).

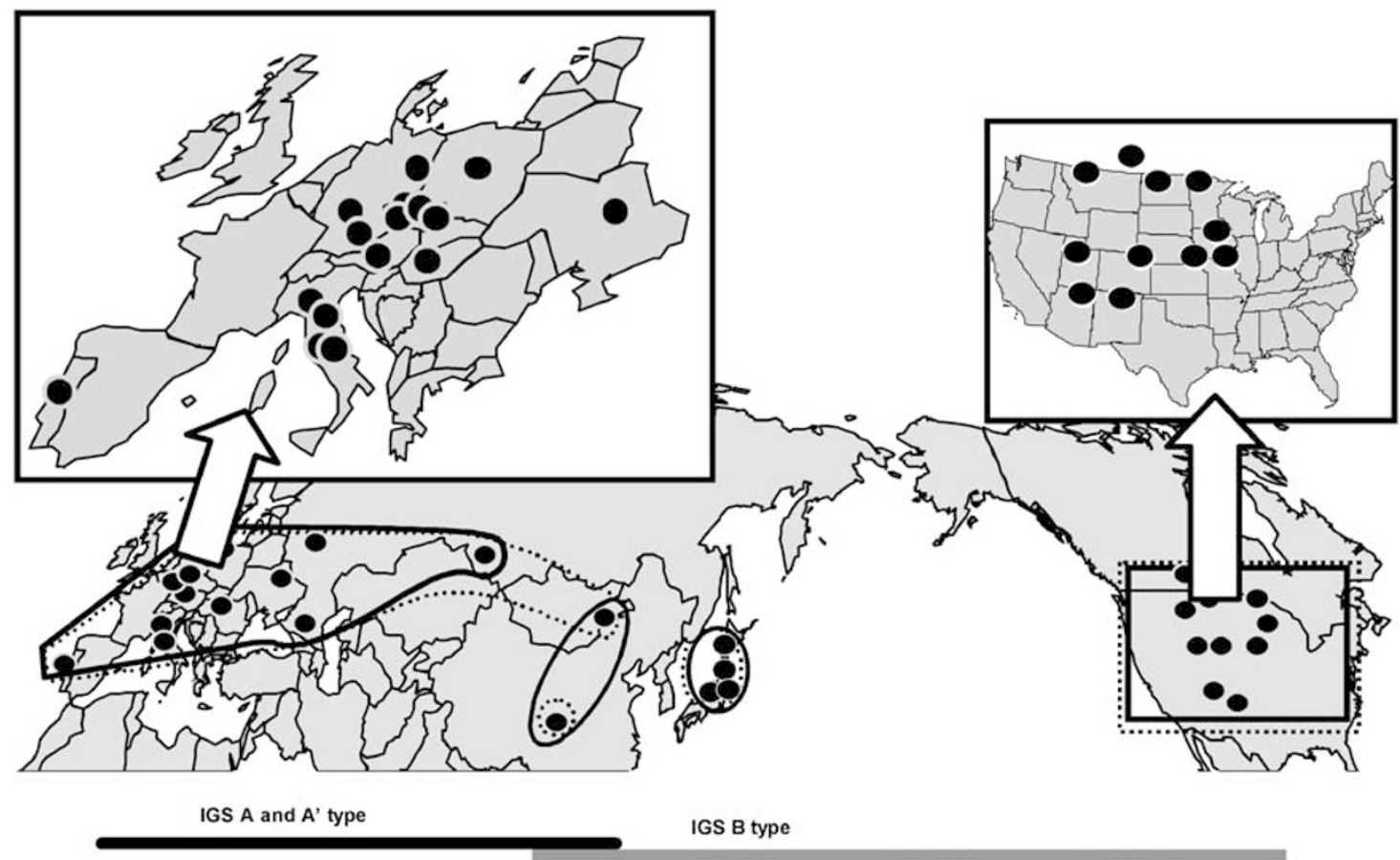

Figure 1 Geographical locality of samples and distribution of haplotypes. Black circle indicates the location of samples used in the analyses. Solid and dotted lines show distribution of cpDNA and ETS sequence defined haplotypes, respectively. Distribution of two IGS length haplotypes is also shown as horizontal bars. 
Table 1 Summary of haplotypes defined by nuclear and chloroplast DNA

\begin{tabular}{|c|c|c|c|c|c|}
\hline \multirow[t]{3}{*}{ Area } & \multirow[t]{3}{*}{ Country } & \multicolumn{4}{|c|}{ Haplotypes (number of samples) } \\
\hline & & \multicolumn{2}{|c|}{ Nuclear } & \multicolumn{2}{|c|}{ Chloroplast } \\
\hline & & IGS & ETS & Sequence & Indel \\
\hline Europe & $\begin{array}{l}\text { Germany } \\
\text { Czech } \\
\text { Portugal } \\
\text { Othera }^{a}\end{array}$ & $\begin{array}{l}\mathrm{A}(12) \\
\mathrm{A}(36) \\
\mathrm{A}(20) \\
\mathrm{A}(11)\end{array}$ & $\begin{array}{l}E(12) \\
E(36) \\
E(20) \\
E(11)\end{array}$ & $\begin{array}{l}\text { cpE(12) } \\
\text { cpE(18) } \\
\text { cpE(14) } \\
\text { cpE(11) }\end{array}$ & $\begin{array}{l}\operatorname{inE}(12) \\
\operatorname{inE}(18) \\
\operatorname{inE}(14) \\
\operatorname{inE}(11)\end{array}$ \\
\hline Altai & & $A(2)$ & $\mathrm{E}(2)$ & $\mathrm{cpE}(2)$ & $\operatorname{inE}(2)$ \\
\hline Caucasus & & $\begin{array}{l}\mathrm{A}(1) \\
\mathrm{A}^{\prime}(2)\end{array}$ & $\begin{array}{l}E(1) \\
E^{\prime}(2)\end{array}$ & $\begin{array}{l}\operatorname{cpE}(1) \\
\operatorname{cpE}^{\prime}(2)\end{array}$ & $\operatorname{inE}(3)$ \\
\hline Asia & $\begin{array}{l}\text { Northern China }{ }^{b} \\
\text { Southern China }{ }^{c} \\
\text { Japan }\end{array}$ & $\begin{array}{l}\mathrm{A}(3) \\
\mathrm{B}(2) \\
\mathrm{B}(34)\end{array}$ & $\begin{array}{l}\mathrm{E}(3) \\
\mathrm{SC}(2) \\
\mathrm{J}(25) \\
\mathrm{J}^{\prime}(9)\end{array}$ & $\begin{array}{l}\operatorname{cpNC}(3) \\
\operatorname{cpSC}(2) \\
\operatorname{cpJ}(34)\end{array}$ & $\begin{array}{l}\operatorname{inNC}(3) \\
\operatorname{inSC}(2) \\
\operatorname{inJ}(34)\end{array}$ \\
\hline North America & $\begin{array}{l}\text { Canada } \\
\text { USA }\end{array}$ & $\mathrm{B}(24)$ & $\begin{array}{l}\text { NA1(19) } \\
\text { NA2(1) } \\
\text { NA3(2) } \\
\text { NA4(2) }\end{array}$ & $\begin{array}{l}\text { cpNA1(3) } \\
\text { cpNA2(15) } \\
\text { cpNA3(8) }\end{array}$ & $\begin{array}{l}\text { inNA1(2) } \\
\text { inNA1 }^{\prime}(1)^{\mathrm{d}} \\
\text { inNA2(15) } \\
\text { inNA3(8) }\end{array}$ \\
\hline
\end{tabular}

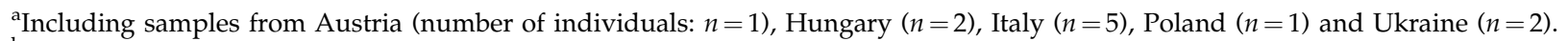

${ }^{\mathrm{b}}$ Collected in either Mongolia or inner Mongolia autonomous region. It was not determined clearly due to poor information on collection.

${ }^{\mathrm{C} C}$ Collected in either Sichuan or Yunnan province.It was not determined clearly due to poor information on collection.

${ }^{\mathrm{d}}$ The inNA and inNA1' differed by one indel, but the remaining sequence was identical as cpNA1.

Table 2 cpDNA noncoding region analysis

\begin{tabular}{|c|c|c|c|c|c|c|}
\hline $\begin{array}{l}\text { Primer } \\
\text { pair }\end{array}$ & $\begin{array}{l}\text { Location of the primer } \\
\text { on cpDNA }\end{array}$ & $\begin{array}{c}\text { Annealing } \\
\left({ }^{\circ} \mathrm{C}\right)\end{array}$ & $\begin{array}{l}\text { Extention } \\
\quad(\text { min })\end{array}$ & $\begin{array}{l}\text { Fragment size } \\
\text { (approx. } k b \text { ) }\end{array}$ & $\begin{array}{l}\text { Primer for } P C R \\
\text { and sequencing, } \\
\text { sequence }\left(5^{\prime}-3^{\prime}\right)\end{array}$ & $\begin{array}{c}\text { No. of nucleotide } \\
(b p)\end{array}$ \\
\hline $\begin{array}{l}\operatorname{trn} \mathrm{H} \\
\operatorname{trn} \mathrm{K}\end{array}$ & $\begin{array}{l}\text { tRNA-His(GUG) } \\
\text { tRNA-Lys(UUU)exon1 }\end{array}$ & 65 & 1 & 1.6 & $\begin{array}{l}\text { ACGGGAATTGAACCCGCGCA } \\
\text { CCGACTAGTTCCGGGTTCGA }\end{array}$ & $\begin{array}{l}604 \\
545\end{array}$ \\
\hline $\begin{array}{l}\operatorname{trn} \mathrm{C} \\
\operatorname{trn} \mathrm{D}(1)\end{array}$ & $\begin{array}{l}\text { tRNA-Cys(GCA) } \\
\text { tRNA-Asp(GUC) }\end{array}$ & 53 & 3 & 2.6 & $\begin{array}{l}\text { CCAGTTCAAATCTGGGTGTC } \\
\text { GGGATTGTAGTTCAATTGGT }\end{array}$ & $\begin{array}{r}975 \\
1160\end{array}$ \\
\hline $\begin{array}{l}\operatorname{trn} \mathrm{D}(2) \\
\operatorname{trn} \mathrm{T}\end{array}$ & $\begin{array}{l}\text { tRNA-Asp(GUC) } \\
\text { tRNA-Thr(GGU) }\end{array}$ & 53 & 1 & 1.2 & $\begin{array}{l}\text { ACCAATTGAACTACAATCCC } \\
\text { CTACCACTGAGTTAAAAGGG }\end{array}$ & $\begin{array}{l}541 \\
595\end{array}$ \\
\hline $\begin{array}{l}p s b \mathrm{C} \\
\operatorname{trnS}(1)\end{array}$ & $\begin{array}{l}\text { psII } 44 \mathrm{kd} \text { protein } \\
\text { tRNA-Ser(UGA) }\end{array}$ & 53 & 1 & 1.6 & $\begin{array}{l}\text { GGTCGTGACCAAGAAACCAC } \\
\text { GGTTCGAATCCCTCTCTCTC }\end{array}$ & $\begin{array}{l}545 \\
577\end{array}$ \\
\hline $\begin{array}{l}\operatorname{trn} \mathrm{M} \\
\operatorname{rbc} \mathrm{L}\end{array}$ & $\begin{array}{l}\text { tRNA-Met(CAU) } \\
\text { RuBisCo large subunit }\end{array}$ & 55 & 3 & 3.0 & $\begin{array}{l}\text { TGCTTTCATACGGCGGGAGT } \\
\text { GCTTTAGTCTCTGTTTGTGG }\end{array}$ & $\begin{array}{l}568 \\
686\end{array}$ \\
\hline $\begin{array}{l}p s a \mathrm{~A} \\
\operatorname{trnS}(2)\end{array}$ & $\begin{array}{l}\text { PS I (P700 apoprotein A1) } \\
\text { tRNA-Ser(GGA) }\end{array}$ & 65 & 3 & 4.0 & $\begin{array}{l}\text { ACTTCTGGTTCCGGCGAACGAA } \\
\text { AACCACTCGGCCATCTCTCCTA } \\
\text { Total }\end{array}$ & $\begin{array}{r}705 \\
712 \\
8213\end{array}$ \\
\hline
\end{tabular}

Figures in parentheses of primer pair indicate different locus or region if they have the same name.

The PCR product of a single band was partially sequenced from the primer used in PCR, and, in the cases of $\operatorname{trn} \mathrm{C}$ and $\operatorname{trn} \mathrm{D}(1)$ regions, additional primers, designated as trnCplus (TATCTTGAGTCTATATTT TTA TAC) and $t r n \mathrm{D}(1)$ plus (GCATTTATTGCTACTGCACT), respectively, were designed and used for further sequencing. Sequencing was performed by a Big Dye Terminator Cycle Sequencing Kit (PE Applied Biosystems) and the ABI PRISM ${ }^{\mathrm{TM}} 3100$ Genetic Analyzer.

Sequences aligned using Clustral W (Thompson et al, 1994) were analysed using MEGA2 (Kumar et al, 2001) and the neighbor joining tree was evaluated by repeating the analysis using 1000 bootstrap samples. For relative rate testing, $H$. Japonicus was used as an out-group. Kimura's two-parameter method was used to determine the nucleotide substitution rate per site. Combined ETS and cpDNA noncoding sequence analysis was also carried out by the maximum parsimony method implemented in MEGA2, using the close neighbor interchange algorithm for branch swapping, random addition, 500 replicates and 100 bootstrap samples. Indels found in cpDNA noncoding regions can also provide evolutionary information (Giribet and Wheeler, 1999) and were used to build a reduced median network using the Network 
software (Bandelt et al, 1995). The sequences used in this study have been registered in DDBJ under the accession numbers AB112490-AB112539, AB112596-AB112655 and AB112750-AB112769.

\section{Results}

\section{Nuclear DNA}

IGS length: The primers for IGS PCR resulted in multiple bands and in order to improve specificity, the '18s-IGS' primer was changed to '19' (Murakami, 2001). A length difference in the single amplified band was found among the wild hops, and it distinguished three haplotypes (Table 1). European, Altai and northern Chinese hops showed a single band of approximately $4.0 \mathrm{~kb}$, designated as IGS A type. Caucasus hops were found to have either IGS A type or a $3.8 \mathrm{~kb}$ band, designated as IGS A' type. Samples from southern China, Japan and North America were characterized by a band of approximately $3.2 \mathrm{~kb}$, designated the IGS B type.

ETS sequence difference: The $537 \mathrm{bp}$ ETS sequence revealed two haplotypes, differing by two nucleotides, in European, Altai and Caucasus hops. They were designated as $E$ and $E^{\prime}$, and were linked with the IGS $A$ and $A^{\prime}$ types, respectively. Northern Chinese hops showed haplotype E, while southern Chinese hops had a different DNA sequence that was designated SC. Two haplotypes differing by a single nucleotide (haplotype J and $\mathrm{J}^{\prime}$ ) were found in Japan. In North American hops, four haplotypes were found, designated as haplotype NA1 through NA4, and the average nucleotide variation among them was 2.27. The number of individuals having each haplotype defined by the ETS sequence is shown in Table 1.

Nucleotide substitution rates among hops grown in each area (group) varied from $0.0113 \pm 0.0045$ (Japan versus southern China) to $0.0170 \pm 0.0057$ (Europe versus Japan). No significant rate differences among the haplotypes were found by the relative rate test using $H$. Japonicus as an out-group. Neighbor joining tree analysis of the haplotypes showed four clades as (i) Europe-Altai-Caucasus-northern China, (ii) North America, (iii) Japan and (iv) southern China, respectively (Figure 2a).

\section{cpDNA}

Sequence differences: In all, 12 cpDNA noncoding regions were combined, and were analysed by the relative rate test using $H$. Japonicus as an out-group. A significantly faster nucleotide substitution rate $(P<0.01)$ was found in European haplotypes, and it seemed to be caused by two regions, $\operatorname{trn} \mathrm{H}$ and $\operatorname{trnS}(1)$. These two regions were therefore excluded, and the remaining $7032 \mathrm{bp}$ of nucleotides were used for the analyses of DNA sequence. Eight haplotypes were distinguished by nucleotide differences found in the cpDNA noncoding regions. Among hops in Europe, Altai and Caucasus, two haplotypes differed by a single nucleotide, and they were designated as $\mathrm{cpE}$ and $\mathrm{cpE}^{\prime}$, respectively. The $\mathrm{cpE}^{\prime}$ haplotype was, however, found only in two of the three Caucasus samples. A two nucleotide difference could distinguish northern Chinese hops (haplotype cpNC) from southern ones (haplotype cpSC). In the North
American hops, three haplotypes were identified (haplotype cpNA1 through cpNA3), and the average nucleotide difference among them was 3.67. There was no variation among Japanese hops (haplotype cpJ). While the nucleotide differences among Chinese, Japanese and North American hops were relatively small, from $0.0009 \pm 0.0003$ to $0.0013 \pm 0.0004$, the comparisons between the haplotypes in Europe, Altai and Caucasus, and the others showed higher values, from $0.0020 \pm 0.0005$ to $0.0024 \pm 0.0006$ (Table 3). Construction of a neighbor joining tree showed four clades: (i) Europe-Altai-Caucasus, (ii) Japan, (iii) Northern-Southern China and (iv) North America. (Figure 2b).

Estimation of divergence time: Evolutionary divergence time was estimated using the molecular clock hypothesis from the combined sequence of cpDNA noncoding regions. The heterogeneity of the nucleotide substitution rate within the genus Humulus was determined by the relative rate test using Cannabis sativa, another member of the Cannabinaceae, as an out-group. Its $r b c \mathrm{~L}$ sequence is available on the DNA data Bank (DDBJ AJ390068). The test revealed nonsignificant rate variation between $H$. lupulus and $H$. japonicus at the third codon position. To estimate the time of divergence between $H$. lupulus and $H$. japonicus, we used a previously reported nucleotide difference of the $r b c \mathrm{~L}$ (Murakami, 2000) and the rate of $1.23 \times 10^{-9}$ per site per year, used for analyses of many species (Xiang et al, 2000). The time of divergence between $H$. lupulus and $H$. japonicus was calculated as 6.38 million years ago which would give an averaged nucleotide substitution rate per site per year of $0.93 \times 10^{-9}$, for combined cpDNA noncoding regions.

Similarly, the time of divergence among Chinese, Japanese and North American haplotypes was estimated as between $0.46 \pm 0.17$ and $0.69 \pm 0.21$ million years ago, while the European haplotypes were estimated to have diverged from the others between $1.05 \pm 0.28$ and $1.27 \pm 0.30$ million years ago (Table 3 ).

\section{Maximum parsimony analysis of combined ETS and cpDNA noncoding region}

Combined sequences of parsimony-informative sites in ETS and cpDNA noncoding regions gave eight haplotypes in North America (ETS and cpDNA haplotype combinations: NA1cpNA1, NA2cpNA1, NA2cpNA2, NA3cpNA1, NA3cpNA2, NA3cpNA3, NA4cpNA1 and NA4cpNA3), while two haplotypes were found in Europe. One haplotype was found both in Southern China and Japan. Northern Chinese hops were excluded from this analysis because of their ambiguous origin.

Parsimony analysis of the 47 informative sites generated three minimal trees with a tree length of 60 substitutions. The trees showed the same topology except for the branching pattern within the North American clade. The overall consistency index was 0.850 and the retention index 0.869 . The bootstrap consensus tree is shown in Figure 2c where the primary division is into European and Asian-North American types. The bootstrap support was high for the European lineage $(100 \%)$ and moderate $(72 \%)$ for the Asian-North American lineage. 


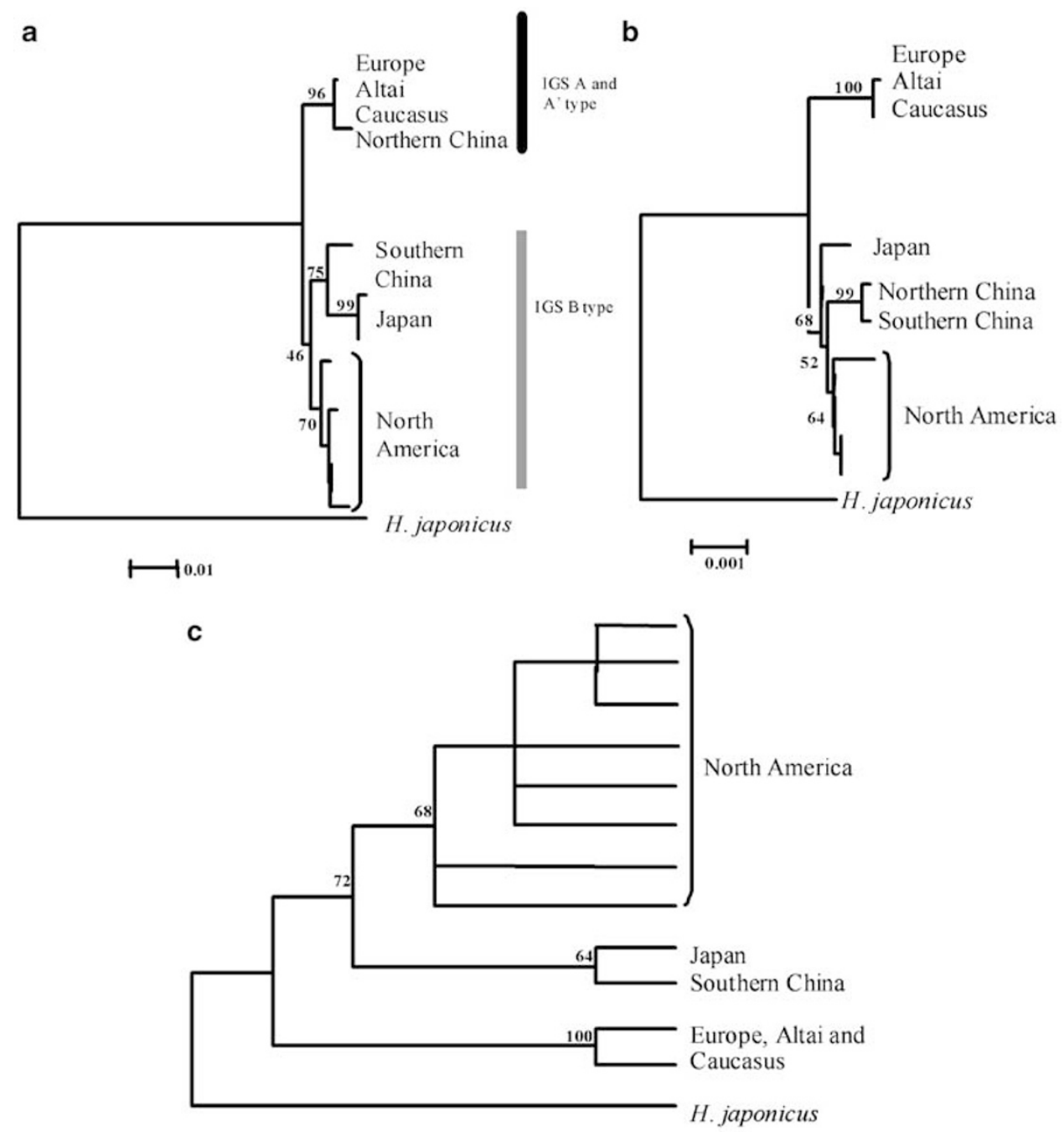

Figure 2 Phylogenetic trees of haplotypes. (a) Neighbor joining (NJ) tree of haplotypes identified by partial external transcribed spacer sequence $(537 \mathrm{bp}$ ) and intergenic spacer (IGS) type of nuclear $26 \mathrm{~s}-18 \mathrm{~s}$ rDNA. For each clade, a 1000 bootstrap value is shown. Vertical bars show IGS types having IGS A and B type with approximately 4.0 and $3.2 \mathrm{~kb}$ lengths, respectively. IGS $\mathrm{A}^{\prime}$ type with approximately $3.8 \mathrm{~kb}$ length is found only in two Caucasus hops. The scale bar indicates nucleotide substitution rate per site determined by Kimura's twoparameter method. (b) NJ tree of haplotypes identified by combined sequence (7032 bp) of cpDNA noncoding regions. For each clade, a 1000 bootstrap value is shown. The scale bar indicates the same as shown in Figure 2a. (c) Maximum parsimony analysis of combined ETS and cpDNA noncoding region. Northern Chinese hop samples were excluded from this analysis because of their ambiguous origin (see text). A total of 47 informative sites generated three minimal trees with tree length of 60 substitutions, an overall consistency index of 0.850 and retention index of 0.869 .

Table 3 Nucleotide substitution rate per site and estimated divergence time based on the difference of combined cpDNA noncoding regions

\begin{tabular}{lcccrr}
\hline & Europe & China & Japan & North America & H. japonicus \\
\hline Europe & & $0.0024 \pm 0.0006$ & $0.0020 \pm 0.0005$ & $0.0020 \pm 0.0005$ & $0.0120 \pm 0.0012$ \\
China & $1.27 \pm 0.30$ & $0.69 \pm 0.21$ & $0.0013 \pm 0.0004$ & $0.0013 \pm 0.0003$ & $0.0122 \pm 0.0012$ \\
Japan & $1.05 \pm 0.28$ & $0.69 \pm 0.18$ & $0.46 \pm 0.17$ & $0.0009 \pm 0.0003$ & $0.0115 \pm 0.0012$ \\
North America & $1.05 \pm 0.26$ & $6.55 \pm 0.64$ & $6.16 \pm 0.65$ & $6.28 \pm 0.64$ & $0.0117 \pm 0.0012$ \\
H. japonicus & $6.45 \pm 0.66$ & & \\
\hline
\end{tabular}

The top diagonal indicates nucleotide substitution rate per site between the populations using Kimura's two-parameter method, and the bottom diagonal shows divergence time $\left(\times 10^{6}\right.$ years $)$ estimated by the averaged rate, $0.93 \times 10^{-9}$ per site per year. All values are obtained using cpDNA noncoding regions, accounting for $7032 \mathrm{bp}$, excluding $t r n \mathrm{H}$ and $t r n \mathrm{~S}(1)$.

\section{Structural differences among hops}

Seven relatively large indels of at least $10 \mathrm{bp}$ were found in the cpDNA sequenced, and they could distinguish seven haplotypes as detailed in Tables 1 and 4 . A reduced median network between the haplotypes is shown in Figure 3, which also contains the position of $H$. japonicus. The primary split of the network separating inE (Europe-Caucasus-Altai) haplotype from the others occurs at this position. From the latter, two lineages appear distinguishing Japanese haplotype, inJ, from 
Table 4 Indels ( $>10 \mathrm{bp}$ ) found in cpDNA noncoding regions

\begin{tabular}{|c|c|c|c|c|c|c|c|}
\hline \multirow[t]{2}{*}{ Area (haplotype) } & \multicolumn{4}{|c|}{ DNA region } & \multirow[t]{2}{*}{$\operatorname{trn} D(2)$} & \multirow[t]{2}{*}{$\operatorname{trn} H$} & \multirow[t]{2}{*}{$\operatorname{trn} M$} \\
\hline & $\begin{array}{c}\operatorname{trn} C \\
1\end{array}$ & 2 & 3 & 4 & & & \\
\hline $\begin{array}{l}\text { Europe,Caucasus and Altai } \\
\text { (inE) }\end{array}$ & - & - & - & - & - & $\Delta 13$ & $\Delta 84$ \\
\hline $\begin{array}{l}\text { Southern China } \\
\text { (inSC) }\end{array}$ & - & - & - & $\Delta 10$ & - & $\Delta 13$ & - \\
\hline $\begin{array}{l}\text { Northern China } \\
\text { (inNC) }\end{array}$ & - & - & - & $\Delta 10$ & - & - & - \\
\hline $\begin{array}{l}\text { Japan } \\
\text { (inJ) }\end{array}$ & - & - & - & - & - & - & - \\
\hline $\begin{array}{l}\text { North America } \\
\quad \text { (inNA1') } \\
\text { (inNA1) } \\
\text { (inNA2) } \\
\text { (inNA3) }\end{array}$ & $\frac{\bar{Z}}{\overline{-30}}$ & $\begin{array}{c}- \\
\overline{\Delta 180} \\
\Delta 180\end{array}$ & $\begin{array}{c}- \\
+32 \\
- \\
-\end{array}$ & $\begin{array}{c}- \\
- \\
\Delta 10 \\
\Delta 10\end{array}$ & $\begin{array}{l}- \\
+22 \\
+22\end{array}$ & $\begin{array}{l}- \\
- \\
-\end{array}$ & $\begin{array}{l}- \\
- \\
-\end{array}$ \\
\hline $\begin{array}{l}\text { Out group } \\
\text { H. japonicus }\end{array}$ & - & - & - & - & - & $\Delta 13$ & - \\
\hline
\end{tabular}

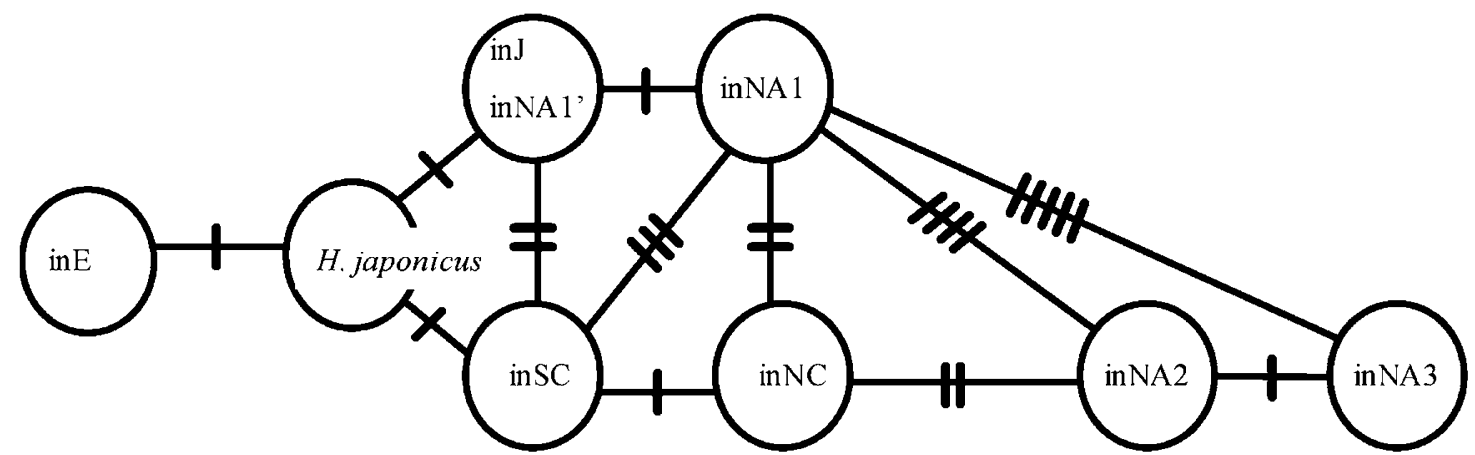

Figure 3 Reduced median network of haplotypes defined by indels found in all cpDNA noncoding regions. A vertical bar on the connected line between haplotypes indicates one indel.

southern Chinese haplotype, inSC. One of haplotypes found in North America, inNA1', shows the same indel as that of inJ, and it connects to inNA1 haplotype. The inNA1 and inNA1' haplotypes differed by one indel (Table 4), but the remaining cpDNA sequence was identical.

The network places Northern Chinese haplotype, inNC, following inSC haplotype. Other haplotypes, inNA2 and inNA3, are on the line from inNC haplotype, showing four and five indel differences from inNA1 haplotype, respectively.

\section{Discussion}

Molecular phylogenies by nuclear DNA, cpDNA and their combined sequence

This study has shown that the phylogenic trees reconstructed from nuclear DNA (ETS) and cpDNA sequence data agree in terms of topology, except for the position of northern China (discussed later). The haplotypes, characterized by ETS, were deeply and primarily divided into European, including Caucasus and Altai hops, and Asian-North American types, although only a poor bootstrap value (46\%) supported the Asian-North American clade (Figure 2a). Analyses both of cpDNA noncoding regions (Figure $2 b$ ) and the combined sequence (Figure 2c) resulted in the same topology showing two clades of Europe and Asia-North America, with the bootstrap values on the trees (Figure $2 b$ and $c$ ) moderately supporting the Asian-North American clade, 68 and 72\%, respectively. Morphological, cytological and chemical studies have also indicated a close relationship between Asian and North American hops (Neve, 1991; Stevens et al, 2000). Thus, Chinese, Japanese and North American wild hops may be closely related to each other.

This study has shown the primary evolutionary divergence to be into European and Asian-North American clades and, although Chinese samples were limited in number, the geographic distribution suggests that this deep divergence occurred in China. Our study differentiated two clades, the European clade located in Western China and the Asian-North American clade in Eastern China, respectively (Figure 1). In addition to the 
haplotype distribution shown here, support for the origin of the genus Humulus and hops, H. lupulus, being in China, as hypothesized by Neve (1991) is provided by the presence of related species, $H$. japonicus and $H$. yunnanensis. These are indigenous only to Eastern Asia (Small, 1978; Neve, 1991) and are not found in North America.

\section{North American hops and migration}

Significant differences in anatomical characteristics among North American hops have been found, and three taxonomic varieties have been identified (Small, 1978). This study showed four and three haplotypes defined by nuclear and chloroplast DNA nucleotides, respectively. At the molecular level, these results confirm a genetic diversity within North American hops. Estimated divergence time among haplotypes within the North American clade varied from 0.08 (cpNA1 versus cpNA2) to 0.54 (cpNA1 versus cpNA3) million years ago, suggesting that the North American population includes both recent and long-diverged haplotypes.

The network of indels places North American haplotypes on the lines extended from Chinese and Japanese haplotypes (Figure 3), suggesting that North American hops are derived from genetically distinct Asian populations, nowadays recognized as Chinese and Japanese hops. This suggests that a heterozygous hop population migrated into North America or, alternatively, that multiple migrations from distinct populations have occurred.

If the origin of hops is, indeed, China (Neve, 1991), migration must have occurred between the continents. In many plant species, an eastern Asia - eastern North America disjunction - has been found (Liu et al, 2002). It is considered to have been formed several million years ago in the late Tertiary period, as estimated from the divergence time between the species Caulophyllum, Penthorum, Phryma, Podophyllum, Decumaria, Campsis and Cornus, in each region. However, one exceptional species, Menispermum, diverged and migrated within the last 0.31 million years, that is, the Quaternary period (Xiang et al, 2000). Our study indicates that North American and Asian hops diverged from $0.46 \pm 0.17$ to $0.69 \pm 0.21$ million years ago in the Quaternary period, and hop migration into North America would appear to have proceeded as for Menispermum species.

\section{Northern Chinese hops}

Northern Chinese hops gave inconsistent results from the nuclear DNA and cpDNA analyses. Nuclear DNA (ETS sequence and IGS length) of Northern Chinese hops was identified unequivocally as of European type, while the sequence of their cpDNA noncoding was close to that of Southern Chinese hops, only differing by two nucleotides, but was rather different from that of European haplotypes, $\mathrm{cpE}$ and $\mathrm{cpE}^{\prime}$, differing by 17 and 16 nucleotides, respectively. These results suggest the possibility that the Northern Chinese samples were a hybrid of Chinese and European hops.

Historical evidence of the origin of hop production in northern China indicates that it began with introduced female hop cultivars from Europe (Barth et al, 1994). Introgression between these introduced cultivars and a wild native population may have produced a haplotype having a mixture of European nuclear and Chinese cytoplasmic DNA. It is clear that further studies are needed to clarify whether they are, indeed, genuine indigenous wild plants.

\section{European hops}

The entire geographical distribution of the European nuclear haplotypes remains unresolved due to the ambiguous origin of our Northern Chinese samples. However, it is evident that the European haplotypes, determined by nuclear DNA and cpDNA, show a wide distribution ranging between Portugal and the Altai region.

Fossil pollen data has shown that European tree species, for example, Oak (Quercus), Pine (Pinus) and Alder (Alnus), migrated and expanded throughout Europe after the last graciation, and a high migration rate was observed, representing from a few hundreds to thousands meters per year (Ferris et al, 1999). Scots pine (Pinus sylvestris) is distributed from Scotland to east Siberia, and the current population structure in Europe was formed 7000-900 years ago (Dvornyk et al, 2002). In North America, lodgepole pine (Pinus contorta) expanded into a range of $2200 \mathrm{~km}$ over 12000 years (Marshall et al, 2002). The distribution of European hop haplotypes found in our study covers a range of $7000 \mathrm{~km}$, calculated as the distance between Portugal and the Altai region. This wide distribution suggests that migration, or gene flow, occurred across Eurasia at a high rate, similar to those for European trees (Ferris et al, 1999).

It has also been suggested that European wild hops themselves originated from past introductions, brought by people migrating from the East, and that they do not represent an autochthonous European plant (Rybáček, 1991; Moir, 2000). If human behavior is involved in hop migration, it would be expected that population size would be reduced. One model of founder speciation involves severe but short-term founder events that reduce microsatellite allele variation by loss of rare alleles without substantially reducing heterozygosity, the test for heterozygosity excess could detect such kind of founder events (Cournuet and Luikart, 1996). A recent microsatellite DNA study of 11 loci (Murakami et al, 2006) analysed wild hops, in almost the same samples used in this study. It found highly polymorphic microsatellites, but no significant excess heterozygosity $(P>0.05)$ in European wild hops, thus providing no evidence of recent founder events of this type.

Nuclear and chloroplast DNA analyses in this study have indicated that genetic differentiation of European hops was found only in the Caucasus region. A phylogenetic tree based on microsatellite DNA also showed the Caucasus hops to be deeply divergent from a large cluster of European hops (Murakami et al, 2006). This differentiation could have arisen if the Caucasus region was genetically isolated from other European populations, perhaps as one of the refugia located in southern Europe area during glacial periods. A similar effect has been observed in some species of European tree (Ferris et al, 1999).

Thus, our study of European haplotype distribution has allowed important aspects of their history to be deduced. The current distribution suggests a similar history to European trees, which are thought to have 
been affected by the last glacial periods. After the last glaciation, hops may have expanded from southern refugia and, since a founder event was not detected, this may have occurred naturally rather than through human association.

Microsatellite analyses indicate that cultivars share alleles with the European native population and would be classified within this population (Jakše et al, 2004; Murakami et al, 2006, unpublished data). This strongly suggests that traditional cultivars were simply selected from natural wild populations, presumably because of their superior qualities for beer production.

\section{Breeding and genetic resources}

Although all modern cultivars have much common ancestry (Seefelder et al, 2000; Jakše et al, 2001), some important characteristics have been derived from wild hops. It appears that high alpha-acids content and resistance to Verticillium wilt disease originated from North American wild hops (Neve, 1991). In this study, North American wild hops were confirmed to be distinct and a high degree of genetic variation still remains within them. Similarly, Japanese and Chinese hops are identified as genetically differentiated hops and thus wild germplasm from these regions may be a new genetic resource to expand genetic variation for breeding. Indeed, a new characteristic, a high level of resistance to aphids, was found in a wild male hop collected in Japan (Darby, 1999).

In addition to the agronomic and brewing characteristics of hops, their pharmacological properties have recently been studied with promising results (eg Stevens et al, 1998). Different compositions of medicinal components have been found in wild hops (Stevens et al, 2000). This strongly suggests that wild hop resources have potential in new applications as well as within the brewing industry.

\section{Acknowledgements}

We thank everyone involved in collecting wild hops for their work and enthusiasm. We specially thank Dr Kenny for providing many of the North American wild samples.

\section{References}

Bandelt HJ, Forster P, Sykes BC, Richards MB (1995). Mitochondrial portraits of human populations. Genetics 141: 743-753.

Barth HJ, Klinke C, Schmidt C (1994). The Hop Atlas, The History and Geography of the Cultivated Plant. Joh. Barth \& Sohn: Nuremberg.

Behre KE (1999). The history of beer additives in Europe - a review. Veget Hist Archaeobot 8: 35-48.

Cournuet JM, Luikart G (1996). Description and power analysis of two test detecting recent population bottlenecks from allele frequency data. Genetics 144: 2001-2014.

Darby P (1999). New selection criteria in hop breeding. In: Seigner E (ed) International Hop Growers' Convention. Proceedings of the scientific commission. Scientific Commission of the IHGC: Huel, Pulawy. pp 3-6.

Delyser DY, Kasper WJ (1994). Hopped beer: the case for cultivation. Econom Bot 48: 166-170.

Demesure B, Sodzi N, Petit RJ (1995). A set of universal primers for amplification of polymorphic non-coding regions of mitochondrial and chloroplast DNA in plants. Mol Ecol 4: 129-131.
Dvornyk V, Sirviö A, Mikkonen M, Savolainen O (2002). Low nucleotide diversity at the pal1 locus in the widely distributed Pinus sylvestris. Mol Bio Evol 19: 179-188.

Ferris C, King RA, Hewitt GM (1999). Isolation within species and the history of glacial refugia. In: Hollingsworth PM, Bateman RM, Gornall RJ (eds) Molecular Systematics and Plant Evolution. Taylor Francis: London, pp 20-34.

Giribet G., Wheeler WC (1999). On gaps. Mol Phylogenet Evol 13: 132-143.

Jakše J, Kindlhofer K, Javornik B (2001). Assessment of genetic variation and differentiation of hop genotypes by microsatellite and AFLP markers. Genome 44: 773-782.

Jakše J, Statovic Z, Javornik B (2004). Microsatellite variability among wild and cultivated hops (Humulus lupulus L.). Genome 47: 889-899.

Kumar S, Tamura K, Jakobsen IB, Nei M (2001). MEGA2: Molecular Evolutionary Genetics Analysis Software. Arizona State University: Tempe, Arizona (available from www. megasoftware.net ).

Liu J, Chen Z, Lu A (2002). Molecular evidence for the sister relationship of the eastern Asia-North American intercontinental species pair in the Podophyllum group (Berberidaceae). Bot Bul Acad Sinica 43: 147-154.

Marshall HD, Newton C, Ritland K (2002). Chloroplast phylogeography and evolution of highly polymorphic microsatellite in lodgepole pine (Pinus contorta). Theor Appl Genet 104: 367-378.

Moir M (2000). Hops - a millennium review. I Am Soc Brew Chem 58: 131-146.

Murakami A (2000). Comparison of sequence of $r b c \mathrm{~L}$ and noncoding regions of chloroplast DNA and ITS2 region of rDNA in genus Humulus. Breed Sci 50: 155-160.

Murakami A (2001). Structural differences in the intergenic spacer of 18S-26S rDNA and molecular phylogeny using partial external transcribed spacer sequence in hop, Humulus lupulus. Breed Sci 51: 163-170.

Murakami A, Darby P, Javornik B, Pais MSS, Seigner E, Lutz A et al (2006). Microsatellite DNA analysis of wild hops, Humulus lupulus L. Genet Resour Crop Evol (DOI 10.1007/ s10722-005-7765-1).

Neve RA (1991). Hops. Chapman and Hall: London.

Pillay M, Kenny ST (1996). Structure and inheritance of ribosomal DNA variants in cultivated and wild hop, Humulus lupulus L.. Theor Appl Genet 93: 333-340.

Rybáček V (1991). Hop Production. Elsevier: Amsterdam.

Seefelder S, Ehrmaier H, Schweizer G, Seigner E (2000). Genetic diversity and phylogenetic relationships among accessions of hops, Humulus lupulus, as determined by amplified fragment length polymorphism fingerprinting compared with pedigree data. Plant Breed 119: 257-263.

Small EA (1978). Numerical and nomenclatural analysis of morpho-geographic taxa of Humulus. Syst Bot 3: 37-76.

Stevens JF, Miranda CL, Buhler DR, Deinzer ML (1998). Chemistry and biology of hop flavonoids. I Am Soc Brew Chem 56: 136-145.

Stevens JF, Taylor AW, Nickerson GB, Ivancic M, Henning J, Haunold A et al (2000). Prenylflavonoid variation in Humulus lupulus: distribution and taxonomic significance of xanthogalenol and 4'-O-methylxanthohumol. Phytochem 53: 759-775.

Thompson JD, Higgins DG, Gibson TJ (1994). CLUSTAL W: improving the sensitivity of progressive multiple sequence alignment through sequence weighting position-specific gap penalties and weight matrix choice. Nuc Acid Res 22: 4673-4680.

Wilson DG (1975). Plant remains from the Graveney boat and the early history of Humulus lupulus L. in W. Europe. New Phytol 75: 627-648.

Xiang QY, Soltis DE, Soltis PS, Manchester SR, Crawford DJ (2000). Timing the eastern Asian-eastern North American floristic disjunction: molecular clock corroborates paleontological estimates. Mol Phyl Evol 15: 462-472. 


\section{Appendix 1}

Summary of sample.

\begin{tabular}{|c|c|c|c|}
\hline Region & Country & District or origin & Number of individual \\
\hline \multirow[t]{16}{*}{ Europe } & \multirow[t]{3}{*}{ Germany } & Berlin and Ostsee & 4 \\
\hline & & Frankfurt & 1 \\
\hline & & Munich & 7 \\
\hline & \multirow[t]{4}{*}{ Czech Republic } & Žatec & 16 \\
\hline & & Litoměřice and Úštěk & 8 \\
\hline & & Central Moravia & 5 \\
\hline & & Eastern Bohemia & 7 \\
\hline & Portugal & & 20 \\
\hline & \multirow[t]{4}{*}{ Italy } & Garda lake & 1 \\
\hline & & Nera valley & 2 \\
\hline & & Cascia valley & 1 \\
\hline & & Norcia valley & 1 \\
\hline & Austria & Salzburg & 1 \\
\hline & Hungary & Platten lake & 2 \\
\hline & Poland & Kazimierz & 1 \\
\hline & Ukraine & & 2 \\
\hline Caucasus & Russia & & 3 \\
\hline Altai & Russia & Biysk town & 2 \\
\hline \multirow[t]{5}{*}{ Asia } & \multirow[t]{2}{*}{ China } & Inner Mongolia or Mongolia & 3 \\
\hline & & Sichuan or Yunnan & 2 \\
\hline & \multirow[t]{3}{*}{ Japan } & Hokkaido island & 4 \\
\hline & & Northern main island & 14 \\
\hline & & Central main island & 16 \\
\hline \multirow[t]{12}{*}{ North America } & Canada & Saskatchewan & 1 \\
\hline & \multirow{11}{*}{ US } & Montana & 7 \\
\hline & & North Dakota & 2 \\
\hline & & Minnesota & 1 \\
\hline & & Missouri & 1 \\
\hline & & Utah & 1 \\
\hline & & Corolado & 5 \\
\hline & & Iowa & 1 \\
\hline & & Nebraska & 2 \\
\hline & & Arizona & 2 \\
\hline & & New Mexico & 3 \\
\hline & & Total & 149 \\
\hline
\end{tabular}

